\title{
Numeric codes for developmental stages of oat apex in the growing conditions of Southern Finland
}

\author{
PIRJo PEltonen-SAINIO and TiINA PEKKAla
}

\begin{abstract}
Peltonen-Sainio, P. \& PekKala, T. 1993. Numeric codes for developmental stages of oat apex in the growing conditions of Southern Finland. Agric. Sci. Finl. 2: 329-336. (Dept. Plant Production, FIN-00014 University of Helsinki, Finland.)
\end{abstract}

\begin{abstract}
Scales that categorize the development of cereal apex have been introduced by several authors. Daylength markedly affects the rate of apex organogenesis and, hence, numeric codes for developmental stages of apices introduced for lower latitudes cannot be used in Finland without modifying them into a ratio scale. The present study introduces numeric codes that categorize the 22 developmental stages of oat (Avena sativa $\mathrm{L}$.) apex in the growing conditions of Southern Finland. Field experiments, including 14 oat cultivars and six breeding lines that differ in the duration of the period from initiation of double ridges to pollination, were carried out at the Viikki Experimental Farm of the University of Helsinki $\left(60^{\circ} 13^{\prime} \mathrm{N}\right)$ for two years. The numeric codes were established by relating them to cumulated degree days (CDD). This study showed that when estimating the developmental stages of oat apex by calculating CDD from sowing, the error of estimation was \pm 1 stage unit at the most.
\end{abstract}

Key words: oats, apex, developmental stage, degree day, numeric code

\section{Introduction}

Temperature, daylength, and precipitation affect crop growth and development. In cereals, the higher the temperature and the longer the photoperiod, the higher the rate of development and the less leaf, spikelet, and floret primordia per head (RASHID et al. 1984, KIRBY et al. 1985, CAO and Moss 1989, Craufurd and CARTWRIGHT 1989, Miglietta 1989, Peltonen-SAinio 1993). The effects of water deficit on apical development are, however, equivocal. In oats, moderate and severe water stress considerably reduced floret and grain set, but did not affect the duration of pre-anthesis phase (PELTONEN-SAINIO 1991).

Several scales describing the development of cereal apex from initiation of double ridges to pollina- tion have been introduced for use in crop management (Table 1). Precise timing of inputs - e.g., application of supplemental nitrogen according to developmental stages of apices (DARWINKEL 1983, Peltonen and Peltonen 1990, Peltonen 1992) is an important strategy particularly in integrated crop production. Moreover, phenoxy acetic acid herbicides, such as MCPA and 2,4-D, when applied close to the double ridge stage, may cause apex abnormalities including twisted rachis, unilateral spikelet set, fusion of spikelets, branched spikes, and retarded differentiation (ANDERSEN 1954, LOUBSER and CAIRNS 1989). In addition, certain developmental stages of apex may be particularly sensitive to injuries caused by insect pests and pathogens. Markedly reduced grain set, following infection caused by barley yellow dwarf virus at the 
Table 1. Comparison of numeric and letter codes that describe development of apices.

\begin{tabular}{|c|c|c|c|c|c|}
\hline Description" & $\begin{array}{l}\text { ANDERSEN } \\
(1952)^{1,2}\end{array}$ & $\begin{array}{l}\text { BANERJEE } \\
\& \text { WIENHUES } \\
(1965)^{2,3,4}\end{array}$ & $\begin{array}{l}\text { WILLIAMS } \\
(1966)^{3}\end{array}$ & $\begin{array}{l}\text { W ADDINGTON } \\
\text { et al. } \\
(1983)^{2,3}\end{array}$ & $\begin{array}{l}\text { ÅFors } \\
\text { et. al. } \\
(1988)^{1,2,3}\end{array}$ \\
\hline Vegetative cupola stage & $0-1$ & $1-2$ & - & 1 & A \\
\hline Transition apex & - & 3 & 16 & 1.5 & B \\
\hline Early double ridge stage & - & 4 & 22 & 2 & $\mathrm{C}$ \\
\hline Double ridge stage & 2 & $5-6$ & 24 & 2.5 & D \\
\hline Triple mound stage & 3 & 7 & 26 & - & $\mathrm{E}$ \\
\hline Glume primordium present & - & - & 28 & 3 & $\mathrm{~F}$ \\
\hline Lemma and floret primordium present & 4 & 8 & 28 & $3.25-3.5$ & G \\
\hline Stamen primordium present & 5 & 9 & $30-32$ & 4 & $\mathrm{H}$ \\
\hline Pistil primordium present & - & 9 & 32 & 4.25 & I \\
\hline Carpel primordium present & - & 9 & 32 & 4.5 & $\mathrm{~K}$ \\
\hline Carpel surrounded by enlarged stamens & - & $10-11$ & 34 & 5 & $\mathrm{~L}$ \\
\hline $\begin{array}{l}\text { Stylar canal closing, ovarian cavity } \\
\text { still open above }\end{array}$ & 6 & $11-12$ & $34-36$ & 5.5 & M \\
\hline $\begin{array}{l}\text { Stylar canal remaining as a narrow opening } \\
\text { and two short style primordia present }\end{array}$ & 6 & 12 & 36 & 6 & $\mathrm{~N}$ \\
\hline Styles begin elongating, still projecting & 7 & - & - & - & $\mathrm{O}$ \\
\hline Styles strongly elongating & 7 & 13 & 38 & 6.5 & $\mathrm{P}$ \\
\hline $\begin{array}{l}\text { Stigmatic branches differentiating as } \\
\text { swollen cells on styles }\end{array}$ & 7 & 14 & $38-42$ & 7 & Q \\
\hline Stigmatic branches elongating & 8 & 14 & - & - & $\mathrm{R}$ \\
\hline $\begin{array}{l}\text { Unicellular hairs differentiating on ovary } \\
\text { walls, stigmatic branches still elongating }\end{array}$ & 8 & 14 & 42 & 7.5 & $\mathrm{~S}$ \\
\hline $\begin{array}{l}\text { Hairs on ovary wall strongly elongating, } \\
\text { stigmatic branches as well }\end{array}$ & 8 & 14 & $42-46$ & 8 & $\mathrm{~T}$ \\
\hline $\begin{array}{l}\text { Stigmatic branches form a tangles mass } \\
\text { (wheat and barley) and are erect (oats) }\end{array}$ & 9 & 15 & 46 & 8.5 & $\mathbf{U}$ \\
\hline $\begin{array}{l}\text { Style and stigmatic branches erect, } \\
\text { stigmatic hairs differentiating }\end{array}$ & 10 & $16-17$ & 50 & 9 & V \\
\hline $\begin{array}{l}\text { Stigmatic hairs well-developed, } \\
\text { branches spreading outward }\end{array}$ & 10 & 17 & 50 & 9.5 & $X$ \\
\hline $\begin{array}{l}\text { Styles curved outward and stigmatic } \\
\text { branches spread wide, pollen grains on } \\
\text { well-developed stigmatic hairs }\end{array}$ & 10 & 17 & 55 & 10 & $\mathrm{Y}$ \\
\hline
\end{tabular}

" According to Waddington et al. (1983) and ÅFors et al. (1988)

${ }^{1}$ Codes described for oats, ${ }^{2}$ barley, ${ }^{3}$ wheat, and ${ }^{4}$ rye

early reproductive phase of oats, indicates such sensitivity (Peltonen-Sainio and KarJalainen 1990).

When evaluating the effects of management practices and abiotic and biotic stresses on apex organogenesis, numeric codes are needed to categorize the development of apex in a ratio scale.
However, numeric codes earlier introduced for barley and wheat are not linearly related to any factor. Furthermore, the applicability of numeric codes for different genotypes has to be tested because, for example, in the studies of KIRBY and APPLEYARD (1980), barley cultivars responded differently to daylength. 
The present study was carried out to simulate the uniform numeric codes for developmental stages of oat apices. The codes established can be used in the photoperiodic conditions of Southern Finland. Evaluation of performance of different oat lines was based on testing of 20 oat cultivars and breeding lines that differ in duration of the period from initiation of double ridges to pollination.

\section{Material and methods}

Plant material consisted of 14 oat cultivars (Table 2) and six breeding lines bred at the Hankkija Plant Breeding Institute, Finland. The oat lines were tested in experiments at the Viikki Experimental Farm of the University of Helsinki $\left(60^{\circ} 13^{\prime} \mathrm{N}\right)$ in $1989-1990$. A completely randomized block design with four replications in 1989 and three in 1990 was used. Plot size was $10 \mathrm{~m}^{2}$, and 500 viable seeds were sown per $\mathrm{m}^{2}$. Planting date was 27 April in both years, and soil type was sandy clay. $80 \mathrm{~kg} \mathrm{~N}^{-1}\left(\mathrm{NH}_{4} \mathrm{NO}_{3}\right)$ was applied at sowing together with $\mathrm{P}, \mathrm{K}$, etc. fertilizers. Weeds were controlled with MCPA [(4-chloro-2methylphenoxyl)acetic acid] at a rate of $700 \mathrm{~g} \mathrm{ha}^{-1}$ after the double ridge stage.

The developmental stages of the oat apices were recorded from 10 randomly sampled main stems per plot according to the scale introduced by ÅFORS et al. (1988). The stage of development was determined on the terminal spikelet, which is the most advanced spikelet in oats. The interval of plant samplings was between two and seven days depending on the rate of differentiation. Cumulated daily growing degree days (CDD) to reach different developmental stages were calculated using $+5^{\circ} \mathrm{C}$ as the base temperature.

Numeric codes, at ratio scale, for each developmental stage of apex were established to replace the letter codes of ÅFORS et al. (1988). The letter code A was changed to $1, \mathrm{~B}$ to $2, \mathrm{C}$ to 3 and so on. Correlations between these integers that correspond to the letter codes A-Y and the weighted means of CDD required to reach the developmental stages were calculated over years and cultivars (MSTAT Development Team 1989). Regression coefficients
Table 2. Oat cultivars tested in the study, year of release, and country of origin.

\begin{tabular}{lcc}
\hline Cultivar & Year of release & Country of origin \\
\hline Jalostettu maatiainen & 1921 & Finland \\
Osmo & 1921 & Finland \\
Esa & 1922 & Finland \\
Pellervo & 1935 & Finland \\
Sisu & 1948 & Finland \\
Kyrö & 1959 & Finland \\
Ryhti & 1970 & Finland \\
Pol & 1974 & Norway \\
Svea & 1976 & Sweden \\
Puhti & 1978 & Finland \\
Veli & 1981 & Finland \\
Hankkijan Vouti & 1982 & Finland \\
Karhu & 1985 & Sweden \\
Virma & 1988 & Finland \\
\hline
\end{tabular}

were tested with Student's t-test (SAS Institute 1989) and the codes for the different developmental stages adjusted until correlation was absolute $\left(\mathrm{R}^{2}=1.00^{* * *}\right)$. Numeric codes (CODE) over genotypes were established using the formula:

\section{[1] $\mathrm{CODE}=-6.08+0.067 * \mathrm{CDD}$}

where CDD is cumulated degree days required to reach different developmental stages of apex from transition apex to pollination.

\section{Results and discussion}

When evaluating the effects of management practices and abiotic and biotic stresses on apex organogenesis, numeric codes are needed to categorize the development of apex in a ratio scale. In this study, numeric codes were established over 20 genotypes (Table 3). The developmental stage, when carpel primordium is initiated, was not recorded in this study. This stage of apex is rapidly transient and hard to distinguish from the preceding one.

When testing the validity of the regression equation [1] for different years and genotypes, our results showed that CDD from sowing explained 88$99 \%$ of the variation in the developmental stage of 
Table 3. CDD from sowing to reach different developmental stages of apex and estimated numeric codes (CODE) for growing conditions of Southern Finland.

\begin{tabular}{|c|c|c|c|c|c|}
\hline \multirow{2}{*}{$\begin{array}{l}\text { Letter code for } \\
\text { developmental stage } \\
\text { (ÅFors et al. 1988) }\end{array}$} & \multirow{2}{*}{$\begin{array}{l}\text { Number of } \\
\text { observation }\end{array}$} & \multicolumn{3}{|c|}{$\mathrm{CDD}\left({ }^{\circ} \mathrm{C}\right)$} & \multirow[t]{2}{*}{ CODE } \\
\hline & & Mean & S.E. & S.D. & \\
\hline A & 165 & 136 & 1.6 & 16.3 & - \\
\hline B & 215 & 137 & 1.4 & 19.6 & 3.12 \\
\hline $\mathrm{C}$ & 151 & 141 & 1.7 & 8.9 & 3.40 \\
\hline D & 84 & 151 & 2.2 & 14.1 & 4.04 \\
\hline E & 197 & 168 & 1.5 & 6.9 & 5.20 \\
\hline $\mathrm{F}$ & 218 & 173 & 1.4 & 8.7 & 5.51 \\
\hline G & 296 & 191 & 1.2 & 17.8 & 6.70 \\
\hline $\mathrm{H}$ & 186 & 205 & 1.5 & 17.7 & 7.68 \\
\hline I & 189 & 216 & 1.5 & 10.8 & 8.39 \\
\hline K & 0 & - & & - & $9.20^{*}$ \\
\hline $\mathrm{L}$ & 472 & 240 & 0.9 & 18.8 & 10.00 \\
\hline M & 88 & 276 & 2.2 & 26.6 & 12.39 \\
\hline $\mathrm{N}$ & 133 & 291 & 1.8 & 21.2 & 13.41 \\
\hline O & 151 & 303 & 1.7 & 14.7 & 14.51 \\
\hline$P$ & 142 & 310 & 1.7 & 19.6 & 14.70 \\
\hline Q & 150 & 314 & 1.7 & 20.5 & 14.95 \\
\hline$R$ & 102 & 333 & 2.0 & 30.7 & 16.24 \\
\hline S & 121 & 341 & 1.9 & 30.3 & 16.79 \\
\hline $\mathrm{T}$ & 144 & 357 & 1.7 & 29.8 & 17.81 \\
\hline $\mathrm{U}$ & 266 & 378 & 1.3 & 24.7 & 19.28 \\
\hline $\mathrm{v}$ & 159 & 410 & 1.6 & 33.8 & 21.42 \\
\hline $\mathrm{X}$ & 156 & 438 & 1.6 & 27.8 & 23.42 \\
\hline $\mathrm{Y}$ & 315 & 469 & 1.2 & 19.7 & 25.34 \\
\hline
\end{tabular}

" interpolated

apices in 1989 and $95-98 \%$ in 1990 . The median was $98 \%$ in 1989 and $97 \%$ in 1990. Precipitation was higher at pre-anthesis in 1989 than in 1990 (Fig. 1). In 1990, degree days cumulated faster at early growth stages, and double ridges initiated about one week earlier than in 1989. Since then, degree days cumulated more slowly in 1990, and oats pollinated five days later than in 1989.

Comparison of regression coefficients for different oat genotypes by F-test showed that apical development of 11 genotypes did not differ significantly between years. The 11 genotypes are all bred in Finland, whereas the nine genotypes that were excluded from further analyses included, for in- stance, the foreign cultivars. Data on both years for the 11 genotypes were combined and new regression equations were established. Then, CDD from sowing explained $96-98 \%$ of the variation in the development of apices (Table 4). The more advanced the developmental stage, the higher was the deviation from the uniform trend (Fig. 2). Further grouping of oats, e.g., into old and modern cultivars and breeding lines, was not statistically justified. In general, differences in intercepts and regression coefficients between the eleven oat genotypes were modest (Table 4). The relatively homogeneous response of lines to CDD, recorded in this study, can be attributed to resemblance of genetic background 

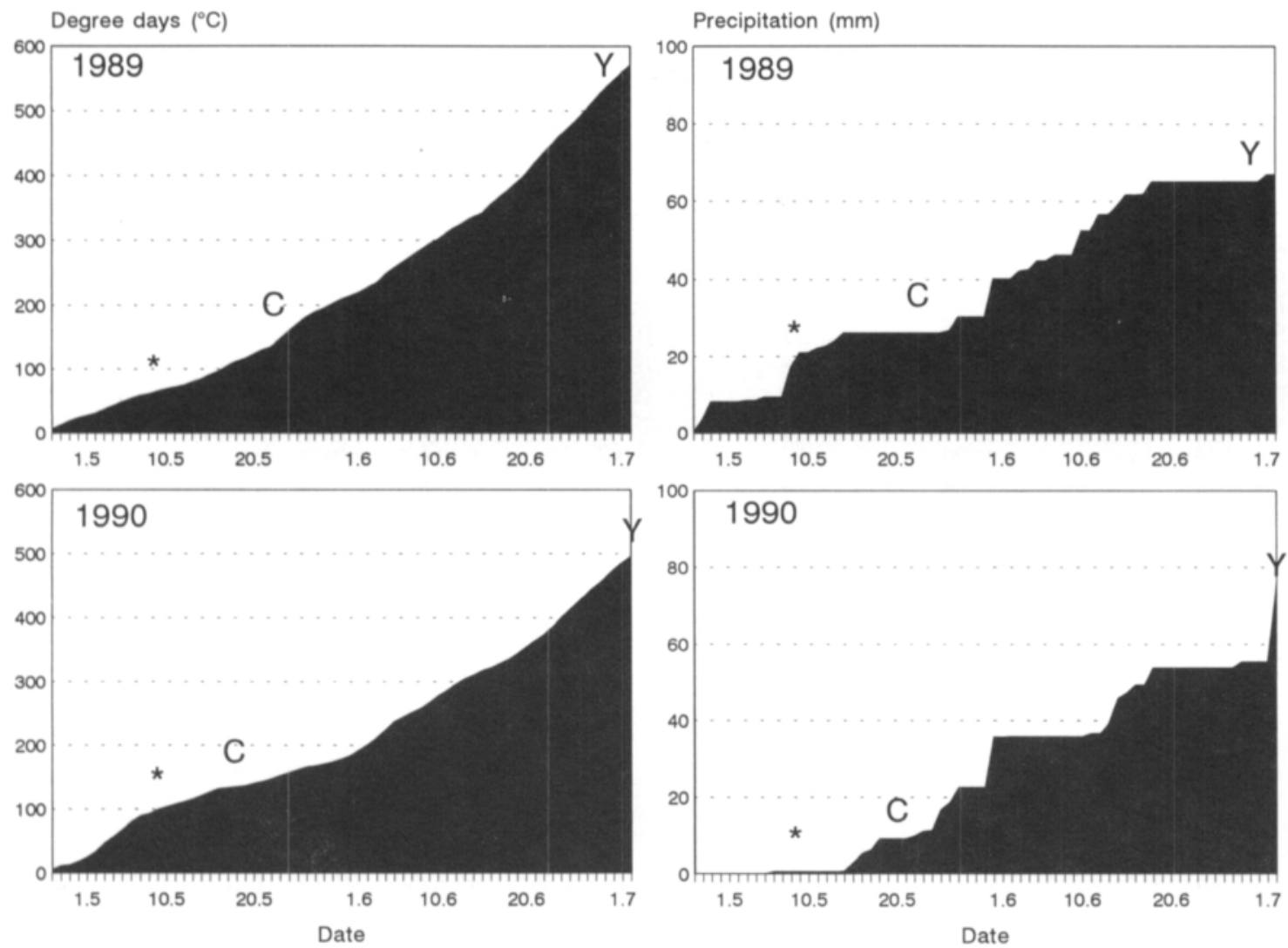

Fig. 1. CDD and precipitation in 1989 and 1990 at Kaisaniemi, Helsinki $(*=$ emergence, $\mathrm{C}=$ double ridge stage, $\mathrm{Y}=$ pollination).

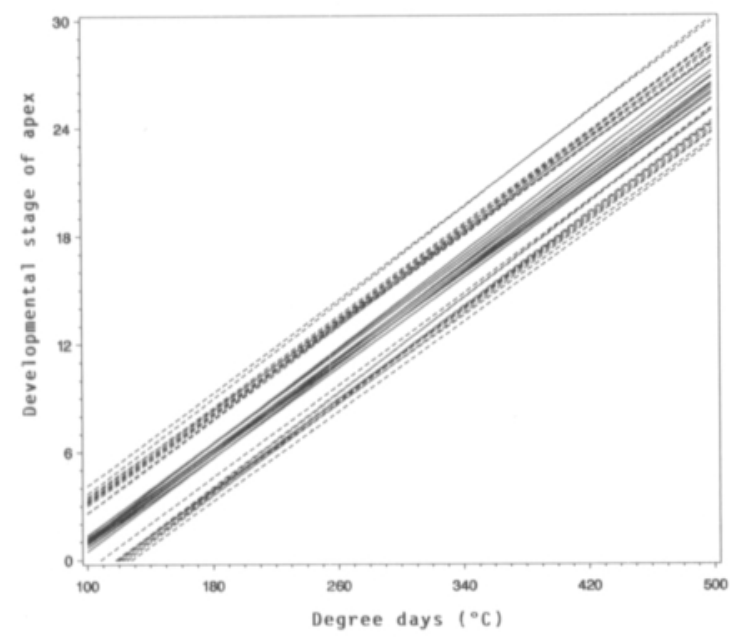

Fig. 2. Regressions between development of apex and CDD in 11 oat lines. Broken lines indicate confidence interval at $95 \%$ level. of oats bred in Finland (REKUNEN 1988, JUSSILA et al. 1992),

Regarding estimation of the developmental stage of apex by calculating CDD from sowing, our results showed that root mean square errors (Root MSE) for different genotypes ranged from 0.94 to 1.39. It means that estimation of developmental stages of apices by calculating CDD from sowing resulted in error of \pm 1 developmental stage unit at the most. The residual scatter plot of cultivar Veli, shown in Figure 3, is similar to that of other cultivars examined. The three developmental stages that may be incorrectly estimated, i.e., they mixed with each other, are when styles began to elongate until stigmatic branches elongated (Fig. 3). Because these stages of apex are particularly rapidly transient, they may mix with each other. Logarithmic modifications of the variables did not improve the 
Table 4. Intercepts and regression coefficients between established numeric codes for developmental stages of apex and CDD in 11 oat cultivars.

\begin{tabular}{|c|c|c|c|c|c|c|}
\hline \multirow[t]{2}{*}{ Cultivar } & \multicolumn{2}{|c|}{ Intercept } & \multicolumn{3}{|c|}{ Regression coefficient } & \multirow[t]{2}{*}{$\mathrm{R}^{2}$} \\
\hline & Estimate & Ratio" & Estimate & Ratio" & $\begin{array}{l}\text { Confidence } \\
\text { interval } 95 \%\end{array}$ & \\
\hline \multicolumn{7}{|l|}{ Jalostettu } \\
\hline maatiainen & -5.29 & 4.2 & 0.064 & 0.011 & {$[0.065,0.063]$} & 0.97 \\
\hline Pellervo & -5.53 & 4.0 & 0.062 & 0.012 & {$[0.063,0.061]$} & 0.97 \\
\hline Sisu & -5.86 & 3.2 & 0.066 & 0.010 & {$[0.067,0.065]$} & 0.98 \\
\hline Ryhti & -5.28 & 3.8 & 0.062 & 0.011 & {$[0.063,0.061]$} & 0.98 \\
\hline Puhti & -5.45 & 4.0 & 0.063 & 0.012 & {$[0.064,0.062]$} & 0.97 \\
\hline Veli & -6.00 & 3.3 & 0.065 & 0.010 & {$[0.066,0.064]$} & 0.98 \\
\hline Hankkijan Vouti & -4.90 & 4.3 & 0.061 & 0.011 & {$[0.062,0.060]$} & 0.97 \\
\hline Hја 76416 & -5.14 & 5.4 & 0.065 & 0.015 & {$[0.067,0.063]$} & 0.96 \\
\hline Hја 76420 & -5.48 & 4.6 & 0.066 & 0.013 & {$[0.068,0.064]$} & 0.97 \\
\hline Hja 78033 & -5.26 & 4.0 & 0.063 & 0.011 & {$[0.064,0.062]$} & 0.97 \\
\hline Hјa 80090 & -5.04 & 3.6 & 0.064 & 0.009 & {$[0.065,0.063]$} & 0.98 \\
\hline
\end{tabular}

"S.E. divided by estimate $(\%)$

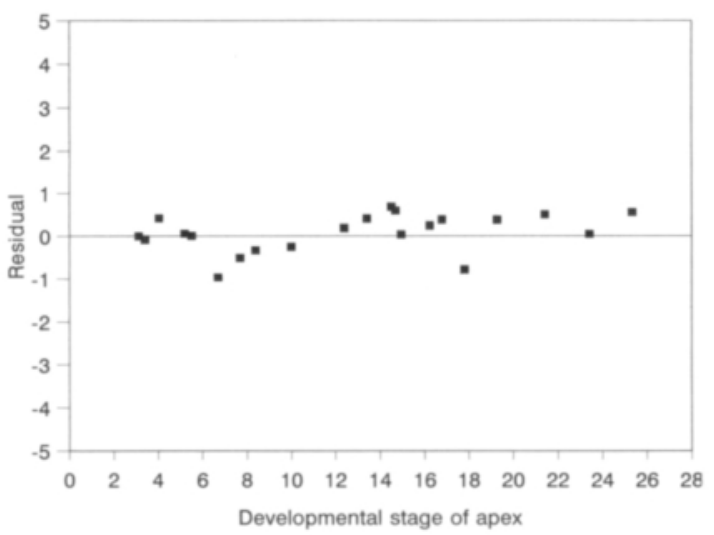

Fig. 3. Residual scatter plot in Veli. Residual was calculated by subtracting the simulated developmental stage from the observed one. validity of estimation of the three developmental stages of apex. However, CDD estimates accurately the double ridge stage and, hence, phenoxy acetic acid herbicides should not be sprayed until $\mathrm{CDD} \geq 170{ }^{\circ} \mathrm{C}$ in oats to avoid apex abnormalities and possible crop losses.

In conclusion, the numeric codes for 22 developmental stages of oat apices were simulated by relating them to CDD. These codes can be used for oats when cultivated in Southern Finland. Our results indicate that estimation of apical development by calculating CDD when timing management practices may result in an error of \pm 1 developmental stage unit at the most.

\section{References}

ÅFors, M., Ohlander, L. \& Stendahl, F. 1988. Stråsädens utveckling I. En litteraturstudie och beskrivning av en skala för bestämning av stråsädens ax- respektive vippanlag. Sveriges Lantbruksuniversitet. Institutionen för växtodlingslära. 75 p. Uppsala.

Andersen, S. 1952. Methods for determining stages of development in barley and oats. Physiol. Plantarum 5: 199210.

- 1954. Effects of 2,4-D on ear development in barley. Physiol. Plantarum 7: 517-522.
BanerJeE, S. \& Wienhues, F. 1965. Comparative studies on the development of the spike in wheat, barley and rye. $\mathrm{Z}$. Pflanzenzüchtg. 54: 130-142.

CAO, W. \& Moss, D.N. 1989. Temperature effect on leaf emergence and phyllochron in wheat and barley. Crop Sci. 29: 1018-1021.

Craufurd, P.Q. \& Cartwright, P.M. 1989. Effect of photoperiod and chlormequat on apical development and growth in a spring wheat (Triticum aestivum) cultivar. Ann. Bot. 63: 515-525. 
DARWINKEL, A. 1983. Ear formation and grain yield of winter wheat as affected by time of nitrogen supply. Neth. J. Agric. Sci. 31: 21 1-225.

Jussila, M., Sontag-Strohm, T. \& Ulvinen, O. 1992. The identification of Finnish oat cultivars (Avena sativa L.) by the use of SDS-PAGE of the avenins in homogeneous and gradient gels. Acta Agric. Scand., Sect. B, Soil and Plant Sci. 42: 106-110.

KIRBY, E.J.M. \& APPLEYARD, M. 1980. Effects of photoperiod on the relation between development and yield per plant of a range of spring barley varieties. Z. Pflanzenzüchtg. 85: 226-239.

-, Appleyard, M. \& Fellowes, G. 1985. Effect of sowing date on main shoot leaf emergence and number of leaves of barley and wheat. Agronomie 5: 117-126.

LOUBSER, J.M. \& CAIRnS, A.L.P. 1989. Abnormalities of the growth point and ear of barley caused by 2,4-dichlorophenoxy acetic acid. South African J. Plant Soil 6: 103107.

Miglietta, F. 1989. Effect of photoperiod and temperature on leaf initiation rates in wheat (Triticum spp.). Field Crops Res. 21: 121-130.

MSTAT Development Team 1989. User's Guide to MSTAT-C: A Microcomputer program for the design, management, and analysis of agronomic research experiments. Michigan State Univ., East Lansing.

Peltonen, J. 1992. Ear developmental stage used for timing supplemental nitrogen application to spring wheat. Crop Sci. 32: 1029-1033.

— \& Peltonen, P. 1990. Effect of apical timed urea spraying on yield components and quality properties of spring wheat (Triticum aestivum L.) in greenhouse experiments. Acta Agric. Scand. 40: 33-43.

Peltonen-Sainio, P. 1991. Effect of moderate and severe drought stress on the pre-anthesis development and yield formation of oats. J. Agric. Sci. Finl. 63: 379-389.

- 1993. Response to daylength in oats: Pre-anthesis development and set of spikelets and florets. J. Agron. Crop Sci. (in press.)

— \& KarJal.ainen, R. 1990. Yield reduction of oat cultivars in relation to disease development caused by barley yellow dwarf virus. J. Agric. Sci. Finl. 62: 265-273.

Rashid, A.H., Halloran, G.M. \& HamaRashid, A. 1984. Influence of photoperiod on culm elongation and apical development in semi-dwarf and standard-height wheats. Ann. Bot. 54: 375-382.

REKUNEN, M. 1988. Advances in the breeding of oats. Comparative trials with historical varieties in 1977-1987. J. Agric. Sci. Finl. 60: 307-321.

SAS Institute 1989. User's Guide. Vol. 1. Anova-Freq. and Vol. 2. GLM-VARCOMP. Version 6. SAS Institute Inc., Cary N.C., USA.

Wadington, S.R., Cartwright, P.M. \& Wall, P.C. 1983. A quantitative scale of spike initiation and pistil development in barley and wheat. Ann. Bot. 51: 119-130.

WiLliams, R.F. 1966. The physiology of growth in the wheat plant. III. Growth of the primary inflorescence. Aust. J. Biol. Sci. 19: 949-966.

\section{Manuscript received April 1993}

Pirjo Peltonen-Sainio

Tiina Pekkala

Department of Plant Production

Section of Crop Husbandry

Box 27, Viikki

FIN-00014 University of Helsinki, Finland 


\title{
SELOSTUS
}

\section{Kauran kukinnon kehitysvaiheiden lukuarvot Etelä-Suomen kasvuoloissa}

\author{
PirJo Peltonen-Sainio ja TiInA PEKKala
}

\author{
Helsingin yliopisto
}

Viikin koetilalla tutkittiin vuosina 1989 ja 1990 tehoisan lämpötilasumman ja kauran kukinnon kehittymisen välistä yhteyttä. Tutkimusaineistona oli 20 kauralajiketta ja -linjaa, joiden tiedettiin aikaisempien kokeiden perusteella eroavan pölyttymisajankohdaltaan. Aineiston perusteella luotiin $22 \mathrm{ku}$ kinnon kehitysvaiheelle (siirtymävaiheesta pölyttymiseen) suhdeasteikolla olevat numerokoodit, joita voidaan käyttää kaikille kauralajikkeille Etelä-Suomen kasvuoloissa.

Tutkimuksessa selvitettiin myös voidaanko kauran kukinnon kehitysvaiheita arvioida epäsuorasti laskemalla tehoisa lämpötilasumma. Tutkimus osoitti, että tảmä menetelmä saat- toi aiheuttaa enimmillään yhden kehitysvaiheen virheen. Tosin esimerkiksi kaksoiskehävaihe, joka on herkkä fenoksiherbisidien (esim. MCPA) aiheuttamille vioituksille, voitiin arvioida luotettavasti. Rikkakasveja ei tulisi torjua fenoksiherbisideillä ennenkuin tehoisaa lämpötilasummaa on kertynyt vähintään $170^{\circ} \mathrm{C}$. Tällöin pääverson neljäs kasvulehti on työntymässä ulos lehtitupesta. Lisätutkimuksia tarvitaan parantamaan kehitysvaiheiden epäsuoraa arviointia - erityisesti helposti tutkittavien, ulkoisten morfologisten ominaisuuksien avulla. 